\title{
Adenoviral Gene Therapy for Pancreatic Cancer: Where Do We Stand?
}

\author{
Koert F.D. Kuhlmann ${ }^{a}$ Dirk J. Gouma ${ }^{a} \quad J o h n$ G. Wesseling ${ }^{b}$ \\ a Department of Surgery and ${ }^{\mathrm{b}}$ Laboratory of Experimental Hepatology, AMC Liver Center, Academic Medical \\ Center, University of Amsterdam, Amsterdam, The Netherlands
}

Key Words

Pancreatic cancer · Gene therapy · Adenovirus

\begin{abstract}
Background: The prognosis of patients with pancreatic cancer is poor. This is mainly caused by the late diagnosis, the aggressive biology and the lack of effective treatment modalities. Adenoviral gene therapy has the potential to selectively treat both primary tumor and (micro)metastatic tissue. Methods: This review provides an overview of what has been achieved so far in the field of adenoviral gene therapy for pancreatic cancer. Results: Transductional targeting allows decreased toxicity due to vector dissemination to nontarget cells and permits delivery with a lower viral dose. It can evade or diminish the immune response, which remains a major problem. Transcriptional targeting evolves quickly but essential drawbacks such as the lack of an efficient animal model delay clinical application. Few clinical trials utilizing adenoviruses have been performed in patients with pancreatic cancer today. Worldwide, only seven phase III trials are being performed investigating adenoviral vectors in cancer patients. Conclusion: A clear therapeutic effect of adenoviral gene therapy in pancreatic cancer has not yet been achieved, because the step from bench to bedside has encountered drawbacks. Combinations of the different targeting strategies and techniques to evade the immune system harbor the future for adenoviral gene therapy in patients with pancreatic cancer.

Copyright $\odot 2008$ S. Karger AG, Basel
\end{abstract}

\section{Introduction}

Pancreatic cancer is the fourth leading cause of cancer-related death with approximately 38,000 newly diagnosed patients in the USA each year [1]. The prognosis of patients with pancreatic cancer is poor, indicated by the fact that the incidence reaches mortality and that 5-year survival is low [2]. Several factors cause this poor prognosis. Tumor biology of pancreatic cancer presumably plays the most important role. Pancreatic adenocarcinoma is highly malignant and has the capacity to infiltrate and metastasize early. Furthermore, the late onset of symptoms leads to diagnosis at an advanced stage of the disease in most patients. Anatomy also plays a role because the pancreas is closely surrounded by vital structures such as the superior mesenteric vein and the portal vein. Tumor ingrowth in these structures takes away the chance of a complete resection of the pancreatic tumor. The advanced stages of pancreatic cancer are associated with substantial morbidity such as cachexia and pain resulting in rapid deterioration. Finally, a major determinant in the poor prognosis is the fact that pancreatic cancer is fairly resistant to most treatment regimes tested to date, such as chemo-, radio- or immunotherapy [3-6]. Gemcitabine was tested in a randomized trial and resulted in a significant improved 5-year survival rate of $21 \%$ compared to $8 \%$ in pancreatic cancer patients who did not receive gemcitabine $(\mathrm{p}=0.009)$ [3].

\section{KARGER \\ Fax +4161306 1234 \\ E-Mail karger@karger.ch}

www.karger.com (c) 2008 S. Karger AG, Basel

$0253-4886 / 08 / 0254-0278 \$ 24.50 / 0$

Accessible online at:

www.karger.com/dsu
Koert F.D. Kuhlmann, MD, PhD

Academic Medical Center, University of Amsterdam, Department of Surgery

Meibergdreef 9, NL-1105 AZ, Amsterdam (The Netherlands)

Tel. +31 20566 2166, Fax +31206914858

E-Mail k.f.kuhlmann@amc.uva.nl 
Fig. 1. Schematic structure of the human adenovirus.

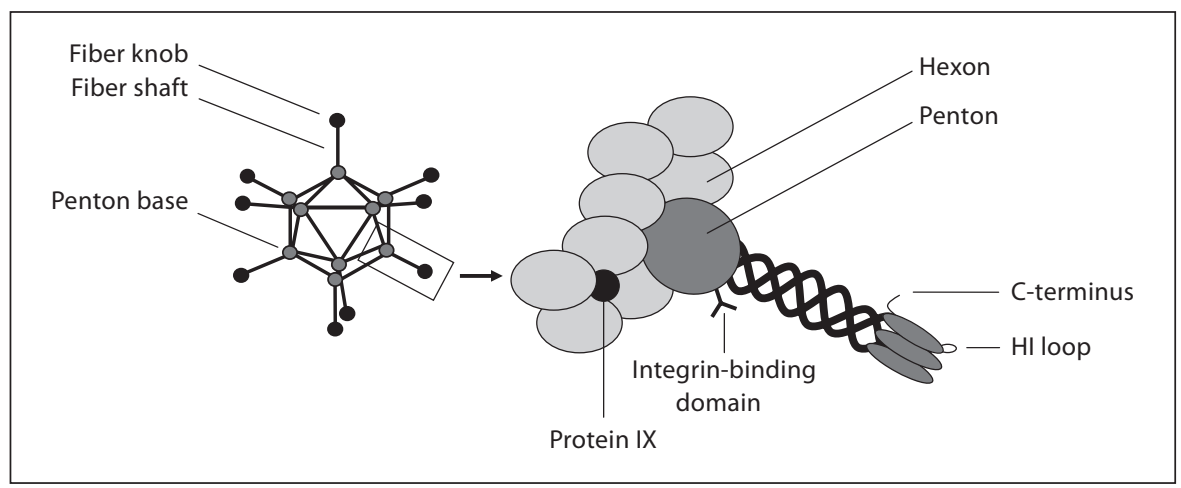

The only treatment option with a curative intention is surgical intervention by means of a pancreatic resection (pancreaticoduodenectomy or Whipple's resection). Due to the high percentage of patients with locally advanced metastatic disease at diagnosis, only $10-20 \%$ of patients are eligible for curative surgery [7]. The median survival of these most optimally treated patients is only 17 months [2]. Thus, it is clear that novel treatment modalities that do have an effect on survival of patients with pancreatic cancer are urgently needed. Adenoviral gene therapy has for many years been regarded as a potential new treatment modality. The aim of this review is to provide an update of what has been accomplished in the field of adenoviral gene therapy today and is focused on the application of gene therapy for pancreatic cancer.

\section{Adenoviruses: Structure and Biology}

Adenoviruses were first isolated from adenoid tissue in 1953. They can cause a wide range of mainly mild symptoms of the respiratory, gastrointestinal and urinary tract and the eye. Adenoviruses are non-enveloped and have a capsid of 20 triangular surfaces that form the icosahedral structure with a diameter of $80-110 \mathrm{~nm}$. They contain a linear, double-stranded, DNA genome of approximately $36 \mathrm{~kb}$. The most important proteins of the capsid of the adenovirus are the hexon, penton base, protein IX and knobbed fiber (fig. 1). At present, 51 distinct serotypes have been recognized which are divided in six subgenera. Serotype 5 (Ad5, subgroup C) has been studied most extensively and is most frequently used in human clinical gene therapy trials [8]. These serotypes have different tissue tropism, which is determined by capsid proteins and most importantly the fiber knob [9]. In the clinical setting, liver tropism of Ad5 is most relevant due to the substantial side effects that can be caused by liver

Adenoviral Gene Therapy for Pancreatic Cancer damage. Although the mechanisms of this tropism to the liver are not fully known, it is partially caused by the abundant expression of the coxsackie-adenovirus receptor (CAR) on hepatocytes, the fenestration of adenovirus in the liver sinusoids and their clearance by Kupffer cells $[10-12]$.

The process of target cell entry of Ad5 starts with the binding of the fiber knob to the CAR, a cell-cell adhesion protein involved in tight junction formation (fig. 2a) [13]. Thereafter, internalization through endocytosis is mediated by the interaction of cellular $\alpha_{\mathrm{v}} \beta$ integrins and the adenoviral Arg-Gly-Asp (RGD) motif in the penton base [14]. In addition to CAR and integrins, recent studies suggest that other receptors, including heparan sulfate proteoglycans and major histocompatibility complex I, may play a role in Ad5 entry into cells $[15,16]$. Once inside the cell, the virus escapes the endosome and translocates to the nuclear pore complex, where the viral DNA is released into the nucleus. Adenovirus transcription occurs in an early and late phase. The early transcriptional genes are E1A, E1B, E2, E3 and E4. E1A leads to activation of the cell cycle and initiation of DNA replication. E1B blocks the apoptotic pathway, induced by E1A activity. E2 is needed for viral DNA replication, E3 modulates the host immune response and E4 regulates DNA replication, mRNA transport and apoptosis. The structural viral proteins are encoded by genes in the late phase of viral replication.

\section{Adenoviral Vectors and Human Gene Therapy}

Currently, human adenoviral vectors (mainly based on Ad5) are being used in approximately one quarter of all gene therapy trials, predominantly for the treatment of cancer [17] (http://www.wiley.co.uk/genmed/clini$\mathrm{cal} /$ ). They are one of the most attractive therapeutic vec- 


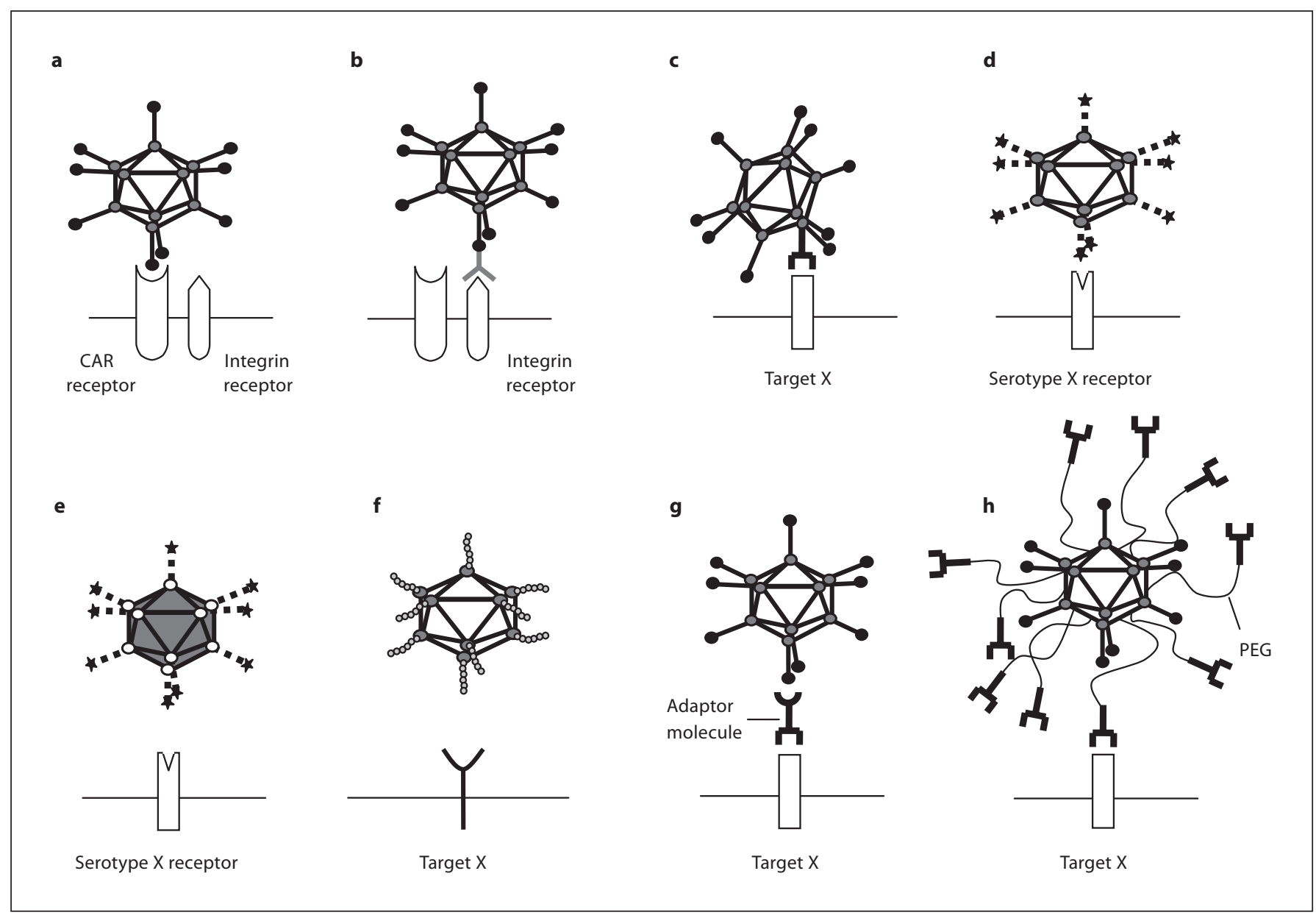

Fig. 2. Schematic representation of different strategies of transductional targeting: a natural target cell attachment, $\mathbf{b}$ knob modification, $\mathbf{c}$ penton modification, $\mathbf{d}$ fiber-chimeric adenovirus, $\mathbf{e}$ serotype switch, $\mathbf{f}$ fiber replacement, $\mathbf{g}$ application of an adaptor molecule, and $\mathbf{h}$ chemical modification.

tors for several reasons. They have the ability to infect both dividing as well as non-dividing tumor cells. They are stable, double-stranded DNA viruses that can be manipulated relatively easily. Furthermore, the techniques to produce high-titered preparations of adenoviral vectors are straightforward.

There are three potential hurdles in the application of adenoviral vectors for the treatment of pancreatic cancer. First, pancreatic adenocarcinoma, as well as many other malignancies, does not express adequate levels of CAR, the receptor to which the natural tropism of Ad5 is directed, to permit efficient cell entry [18-20]. Second, expression of CAR on healthy tissue may lead to vector- or transgene-related toxicity through the entry of adenoviral vectors into non-target cells. Third, the innate immune response towards the vector is dose-dependent and can lead to neutralization of the adenoviral vectors and to a deadly systemic inflammatory response [21]. These potential disadvantages highlight the importance of understanding the role of native adenoviral receptors in gene transfer in vivo and of developing targeted adenovirus vectors with improved efficiency and specificity of gene transfer to pancreatic tumor cells.

Generally, modification of the adenoviral vectors can result in transductional or translational targeting. Transductional targeting implies adenoviral modifications that redirect the adenoviral vector to a ligand specifically expressed on the target cell. Translational targeting implies modifications that restrict gene expression to the target cell. The gene-directed prodrug activation therapy system can be used to achieve local high concentrations of toxic drugs into tumor tissue. 


\section{Modification of the Adenoviral Tropism: Transductional Targeting}

Because of the described limitations of Ad5 as a gene therapy vector, a lot of effort has been put into the modification of the tropism of the virus. It allows transductional targeting to tumor cells and decreases toxicity due to vector dissemination to non-target cells and permits delivery with a lower viral dose. Several approaches have been developed, such as modifications of Ad capsid proteins, mainly the fiber knob, conjugation-based modifications using an antibody or bispecific fusion protein, and chemical modifications of the adenoviral vector using polymers containing targeting ligands. This strategy can be complex because genetic modifications can lead to destabilization of the fiber, causing loss of trimerization resulting in a non-functional virus.

\section{Genetic Modification of the Fiber Knob}

Krasnykh et al. [22] identified the HI loop in the Ad knob monomer as a potential site for genetic modification of the Ad fiber. The HI loop is exposed on the knob of the fiber and has a certain degree of flexibility. It can tolerate peptide insertions of up to 100 amino acids, with minimal negative effects on virion integrity. Incorporation of foreign peptides into the $\mathrm{HI}$ loop, the $\mathrm{C}$-terminus of the fiber knob or a combination of both have been investigated extensively $[23,24]$. The cloning of the ArgGly-Asp (RGD) peptide, originally located at the penton base, into the HI loop of the fiber knob results in vitro and in vivo an improved targeting to $\alpha_{\mathrm{v}} \beta$ integrins of pancreatic carcinoma and also of other human tumors (fig. 2b) $[14,18,22,25,26]$. There are also multiple studies that report the insertion of other peptides into the HI loop of the fiber knob, for example those discovered by phage display [27-29]. Although the target of these peptides is often unknown, the viruses show enhanced transduction to multiple cell types including cancer cells. Double modifications of the fiber knob were performed by insertion of a stretch of seven lysine residues $\left(\mathrm{K}_{7}\right.$ peptide) into the C-terminus of the fiber knob which target to the heparan sulfates of the cellular surface, while RGD was inserted into the HI loop [24]. These double modified viruses were more efficient than both single modified viruses concerning gene transfer to multiple cancer cells.

\section{Other Capsid Modifications}

It is also possible to retarget adenoviral vectors by inserting peptides into capsid protein pIX, penton and hexon, although these are not directly involved in target cell attachment (fig. 2c). Based on the proposed structure of pIX, a heparan sulfate-binding motif (polylysine) was inserted into the $\mathrm{C}$-terminus which resulted in fiber knobindependent transduction of CAR-deficient cell types [30]. It was also shown that the C-terminus of pIX tolerates the insertion of large peptides, which is important for cell type-specific targeting [31]. Accessibility of the incorporated peptide at the capsid surface was improved by incorporation of a spacer [32]. The RGD motif in the penton base can be replaced by a peptide that can recognize tissue-specific integrins [33]. Vigne et al. [34] showed that the RGD peptide can be incorporated into the hexon leading to targeting of the modified adenoviral vector to vascular smooth muscle cells.

\section{Fiber-Chimeric Adenoviral Vectors}

Another approach to modify Ad5 is the substitution of the complete Ad5 fiber knob by fibers derived from other Ad serotypes (fig. 2d). These fibers are mainly from subgroup B because, in contrast to most serotypes from the other subgroups, they use a receptor for initial cell attachment other than CAR [35-38]. Subgroup B adenoviruses, including Ad3, Ad11, Ad14, Ad16, Ad21, Ad35 and Ad50, use other molecules for infection, such as CD46, CD80 and CD86 [39-41]. Several adenoviruses belonging to serotype $\mathrm{D}(\mathrm{Ad} 8, \mathrm{Ad} 19$ and $\mathrm{Ad} 37)$ use sialic acids as the primary receptor $[42,43]$. Primary endothelial cells, smooth muscle cells, synoviocytes, hematopoietic stem cells are poorly transfectable by conventional Ad vectors but were efficiently transfected by fiber-chimeric adenoviral vectors [44-46]. For example, the transduction efficiency of intestinal mucosa can be enhanced using an Ad5 virus bearing subgroup B fibers [47]. Recently, improved gene transfer to primary human pancreatic carcinoma cells was observed using Ad5 containing fibers from serotype 16 and type 50 [Kuhlmann et al., submitted]. Thus, both approaches allow Ad tropism to be expanded (or changed) via binding of the modified fiber of serotype 5 or via a fiber from another serotype.

Another approach to enhance infectivity of Ad vectors is called 'complex mosaicism'. This is a combination of different serotype chimerism and targeting ligand(s) incorporation in the fiber molecule. For example, Borovjagin et al. [48] constructed an Ad containing the RGD-4C peptide into the HI loop, at the carboxy-terminus, or both locales of the Ad $3 \mathrm{knob}$ in the context of the Ad5/3 vector. This vector was simultaneously retargeted to integrins and Ad3 receptors, and showed up to 55-fold increase of gene transfer to bladder cancer cell lines. In this 
case, most retargeting was due primarily to Ad3 retargeting, but also some integrin-mediated targeting was observed.

\section{Serotype Switch}

Using another serotype instead of a fiber-chimeric adenoviral vector could provide additional advantages since most host-neutralizing antibodies are directed towards the penton and hexon capsid proteins (fig. 2e) [49, 50]. In chimeric adenoviral vectors these neutralizing antibodies will still bind to the Ad5 backbone. In the USA, Europe and Asia, preexisting immunity against adenoviral serotype 5 exist in approximately $80 \%$ of the population, compared to $1-15 \%$ for subgroup B adenoviruses indicating that switching to another serotype may solve the problem of readministration of Ad to humans [51, 52]. Recently, serotypes 11 and 35 have been shown to be possible candidates for pancreatic cancer, because both display enhanced infectivity in pancreatic cancer cells [51, $53,54]$.

\section{Fiber Replacement}

Switching of the fiber or serotype only results in the redirection of the adenoviral vector to its natural ligand and often to widespread distribution of the virus to the target tissue but also to normal tissue. Replacing the native Ad fiber with a non-adenoviral chimeric protein allows redirecting the virus to specific surface receptor cells that for example cannot be infected by any Ad serotype (fig. 2f). There are several proof-of-principle studies describing the radical replacement of the adenoviral fiber with a non-adenoviral chimeric protein containing a heterologous trimerization motif and a receptor-binding ligand. Krasnykh et al. [55] replaced the fiber with two amino-terminal repeats of the shaft domain of the Ad5 fiber protein genetically fused with a truncated form of the bacteriophage T4 fibritin protein. Van Beusechem et al. [56] constructed knobless adenoviral vectors with a Myc epitope and a 6His tag to mimic the targeting ligands which lead to mature but unstable virions. As an example of successful targeting via fiber replacement, Belousova et al. [57] functionally displayed the human CD40 ligand in the chimeric fiber of the Ad vector, which infected CD40-positive dendritic cells with high efficiency.

\section{Ablation of Natural Tropism}

So far, all described modifications do enhance adenoviral transduction of (pancreatic) tumor cells by using additional entry pathways to compensate for low CAR expression. Although modified, some of the viruses de- scribed above can still bind to their natural receptor. Therefore, the natural adenoviral tropism should be abolished to achieve selective targeting. There are at least three regions that determine this tropism of Ad5: the fiber knob, the fiber shaft and the RGD motif at the penton base. Mutations in multiple loops of Ad5 fiber knob reduce transduction efficiency by ablating the fiber-CAR interaction [58, 59]. In addition, interaction of the penton base with integrins was abolished by deletion of the RGD motif [60]. A single mutation of either fiber knob or penton base does not change the biodistribution of Ad vectors in mice upon tail vein injection [60,61]. In vivo studies with viruses containing double mutations give conflicting results; some studies report significant reduced liver transduction, while others report no reduction [6264]. An important cause for this observation is the fiber shaft and in particular its length [65-67]. Shortening of the shaft results in lower liver transduction, possibly via elimination of the motif that binds to the heparan sulfate. A triple mutant containing a CAR-binding ablated mutant fiber knob derived from Ad5, a fiber shaft derived from Ad35 (the fiber shaft of Ad35 does not possess the KKTK motif and is shorter than that of Ad5), a fiber tail and a mutant penton base without RGD motif, both derived from Ad5, mediated a 30,000-fold lower level of liver transduction in mice compared to the conventional Ad5 vector [63].

\section{Application of Adaptor Molecules}

Another way to retarget adenoviral transduction can be achieved by complexing bispecific conjugates with the adenoviral vector (fig. $2 \mathrm{~g}$ ). These conjugates have one component directed to a region of the adenoviral vector, often an antibody that binds the fiber knob, and one component directed at a target cell receptor. These conjugates not only change the tropism but also ablate the natural tropism by binding to ligand-binding sites. Many different conjugate types have been generated with affinity to many different cell types. Anti-knob monoclonal antibodies $(\mathrm{mAb})$ have been fused to proteins such as the fibroblast growth factor which enhanced adenoviral transduction of Kaposi's sarcoma [68]. Furthermore, they have been fused with antibody fragments. Fusion with a $\mathrm{mAb}$ against epidermal growth factor receptor (EGFR) for example resulted in EGFR-specific transduction of squamous cell carcinoma of the head and neck [69]. Bispecific conjugates directed to other capsid proteins were used by Wickham et al. [70], who targeted an adenoviral vector with a FLAG peptide incorporated into the penton base to integrins using an anti-FLAG/anti-integrins bi- 
specific antibody. Bispecific fusion proteins consisting of two single-chain Fv domains were developed to direct the adenoviral knob to EGFR [71]. Other bispecific fusion proteins use the extracellular domain of CAR to bind the knob and a conjugate of truncated CAR and EGF has for instance been used to retarget Ad to pancreatic cancer [18].

\section{Chemical Modification}

Human serum is a very hostile environment to most viruses including adenoviruses. This is not only caused by the neutralization of the virus by antibodies, but it is also due to binding to blood cells. Over $90 \%$ of a typical virus dose binds to human (but not murine) erythrocytes ex vivo [72]. Coating of adenoviral vectors in this respect is promising because it could shield the virus from blood cells. Another advantage of this coating is that one could retarget the adenoviral vector using a ligand-specific peptide coating. The polymer polyethylene glycol (PEG) can be covalently attached to free lysine groups on the surface of the adenoviral vector to shield it from its environment [73]. Thus, covalent attachment of PEG to Ad exhibit antibody evasion activity and long plasma halflife. However, these vectors are less effective in cell entry because of the steric hindrance caused by PEG. Eto et al. [74] modified the PEGylated Ad vector by introduction of the RGD motif into the fiber protein. This RGD-PEG-Ad not only showed up to 200 -fold higher gene expression compared to PEG-Ad, but it also retained high activity in the presence of anti-Ad antiserum. Furthermore, RGDPEG-Ad revealed efficient gene expression in both CARpositive and CAR-negative cells, but also in in vivo experiments. Lanciotti et al. [75] coated the adenoviral vector with a conjugate of fibroblast growth factor- 2 and PEG, showing that the transduction of ovarian cancer cells became dependent on the FGF-2 receptor and independent of CAR. In an intraperitoneal model of ovarian cancer, this conjugate mediated increased transgene expression in tumor tissue and at the same time reduced localization of the vectors to non-target tissues compared with unmodified Ad vectors [75].

In conclusion, transductional targeting is a promising strategy to target pancreatic cancer cells. Using different targeting techniques it can enhance cell specificity. Furthermore, it can evade or diminish the immune response, which remains one of the major problems in adenoviral gene therapy. A limitation of this strategy is the fact that it is never $100 \%$ specific and that normal cells can also be infected, possibly leading to safety problems when tested in human gene therapy trials.

Adenoviral Gene Therapy for Pancreatic Cancer

\section{Gene Expression Modifications: Transcriptional Targeting}

Transcriptional targeting can be performed in different ways. An obvious strategy would be the restoration or silencing of a gene specific for pancreatic cancer. However, all types of cancer, including pancreatic cancer, contain mutations in several genes. Furthermore, to effectively treat cancer, every single cell should be hit by an adenovirus which is virtually impossible. Other strategies include conditionally replicating adenoviral vectors (CRAds) which should selectively replicate in tumor cells, leading to oncolysis. They have the theoretical advantage of sparing healthy tissue. Furthermore, the released virus can infect neighboring tumor cells leading to a cascade of tumor destruction and viral replication (bystander effect).

\section{Restoration or Silencing of Pancreatic Cancer-Specific}

Genes

Many mutations in oncogenes and tumor-suppressor genes are associated with pancreatic cancer. The most commonly mutated oncogene is K-ras (in $95 \%$ of patients), and the most commonly mutated tumor-suppressor genes are P16/RB1 (>90\%) and P53 (50-75\%) [76]. In vivo experiments revealed that intraperitoneal injection of adenoviral vectors expressing antisense K-ras RNA suppresses peritoneal dissemination of hamster pancreatic cancer without systemic toxicity [77]. Adenovirusmediated coexpression of antisense K-ras RNA and interferon- $\alpha$ (a cytokine with an anti-growth effect on many malignancies, including pancreatic cancer) has been shown to enhance interferon- $\alpha$-induced cell death and suppress the subcutaneous growth of pancreatic cancer cells in mice [78]. Using the same strategy, the cancer-associated Sm-like (CaSm) oncogene was silenced, resulting in a significantly decreased proliferation and growth of pancreatic tumor cells in vitro [79]. In two studies the wild-type P53 tumor-suppressor gene was reintroduced into pancreatic cancer cell lines using an adenoviral vector, which resulted in induction of apoptosis and inhibition of cell growth $[80,81]$. Another study used adenoviral vectors to reintroduce wild-type P16 and P53 into pancreatic cancer cells in vitro and into subcutaneous pancreatic tumors in an animal model to determine the effect on tumor growth, resulting in significant growth reduction [82]. Rigg et al. [83] observed tumor invasion after adenoviral introduction of tissue inhibitors of metalloproteinase 1 and 2 (TIMP1 and TIMP2). They demonstrated in vitro that the TIMP-expressing pancreatic

Dig Surg 2008;25:278-292 
tumor cells were significantly less invasive than those cells transfected with a control vector. In vivo, adenoviral delivery of TIMP1 or TIMP2 to nude mice harboring intraperitoneal human pancreatic cancer resulted in prolonged survival compared with control mice. To reach curative treatment, this strategy of restoration and silencing needs a transfection efficiency of $100 \%$, which seems impossible to achieve. Because of the multifactorial genetic nature of the disease, it cannot be expected that restoration or silencing of a single gene can cure a pancreatic cancer cell.

\section{Gene-Directed Prodrug Activation Therapy}

This strategy results in the adenoviral delivery of a prodrug activator to the target cell. When the non-toxic prodrug is systemically administrated, only cells containing the prodrug activator are able to convert the nontoxic prodrug into a highly toxic drug. This system provides low systemic but high local intratumoral toxicity. Diffusion of the toxic drug to neighboring cells results in killing of cells that were not transduced. This bystander effect makes it possible that transduction of a relatively low percentage of cells will be sufficient to kill virtually all tumor cells. Cytosine deaminase can convert non-toxic 5-FC into toxic 5-FU and has been shown to be effective in a murine pancreatic cancer model [84]. Herpes simplex virus thymidine kinase (HSV-Tk) can phosphorylate systemically administered gancyclovir which eventually leads to cell death. This system has also shown to result in tumor regression in a pancreatic cancer mouse model [85].

\section{Conditionally Replicating Adenoviral Vectors}

The first described CRAd is based on the fact that the function of tumor-suppressor gene P53 is inactivated in many malignancies, including pancreatic cancer. The human adenoviral E1B gene encodes a protein that inactivates the cellular tumor-suppressor protein P53. Activity of this protein must be blocked in order to allow efficient virus replication. ONYX-015 is an Ad2/5 fiber-chimeric adenoviral vector in which the E1B gene is mutated and therefore absent. This virus is unable to replicate in normal cells but is able to replicate in cells lacking functional $P 53$, such as pancreatic cancer cells [86]. In a phase I/II clinical trial with ONYX-015, endoscopic intratumoral injection was assessed in combination with intravenous gemcitabine in 21 patients with advanced pancreatic cancer [87]. Endoscopic injection was feasible and led to few procedure-related complications. Although it was not the aim of the study, it resulted in a partial response in 2 patients, stable disease in 10 patients and progressive disease in 11 patients. Recent studies have shown that replication of ONYX-015 can be independent of the p53 status, possibly due to inactivation of $P 53$ by other viral genes [88]. ONYX-015 replication depends on an unidentified mRNA transport mechanism that is active in many cancer cells but not in normal cells [89]. Because the clinical outcome of patients undergoing monotherapy with ONYX-015 has been disappointing thus far, E1B-mutated vectors have been further developed. This has led to vectors that can be used to carry genes encoding anti-tumor factors. For example, ONYX-015-expressing endostatin, a strong inhibitor of angiogenesis, has been developed [90]. This virus is capable of replicating in and lysing hepatocellular carcinoma (HCC) cells selectively with effective tumor growth suppression and antiangiogenic activity on HCC xenografts in nude mice.

Other oncolytic adenoviral vectors of importance are those with a mutation in the E1A gene. The E1A protein overcomes the inhibition of cell cycle progression mediated by the retinoblastoma $(\mathrm{Rb})$ pathway. E1 A binds with the retinoblastoma protein $(\mathrm{pRb})$, resulting in the release of cell cycle activators resulting in the progression from G1 to S phase of mitosis. A 24-bp deletion in the pRbbinding region of the E1A region eliminates binding to $\mathrm{pRb}$ and thus results in a virus that cannot overcome the inhibition of the cell cycle by pRb [91]. Since many tumors have defects in the pRb pathway (e.g. Rb mutation, p16 loss, cyclin D amplification), these E1A mutant adenoviral vectors should selectively replicate in Rb-defective cells. Although mutations of the $\mathrm{Rb}$ gene are rarely detected in pancreatic cancer, p16 abnormality is present in $90 \%$ of patients [92]. An E1A-mutated adenoviral vector containing a small deletion in the E1A region efficiently destroyed pancreatic cancer cell lines, while leaving resting, normal cells unharmed [93]. In order to improve the selectivity, an adenoviral vector has been developed with alterations in both E1A and E1B [94]. This virus effectively and selectively replicates in and causes oncolysis of gallbladder carcinoma in vitro and in vivo with reduced negative effects on normal cells. However, because this mutant Ad carries two deletions, its attenuation affects its ability to efficiently replicate and spread to achieve its desired cytopathic effect.

In addition to CRAds made tumor specific by deletion of the E1 region, another option is to generate a vector in which the genes essential for Ad replication are under control of a tumor-specific promoter (TSP) (fig. 3). In recent years, DNA array studies have discovered many potential pancreatic cancer marker genes which can be used 


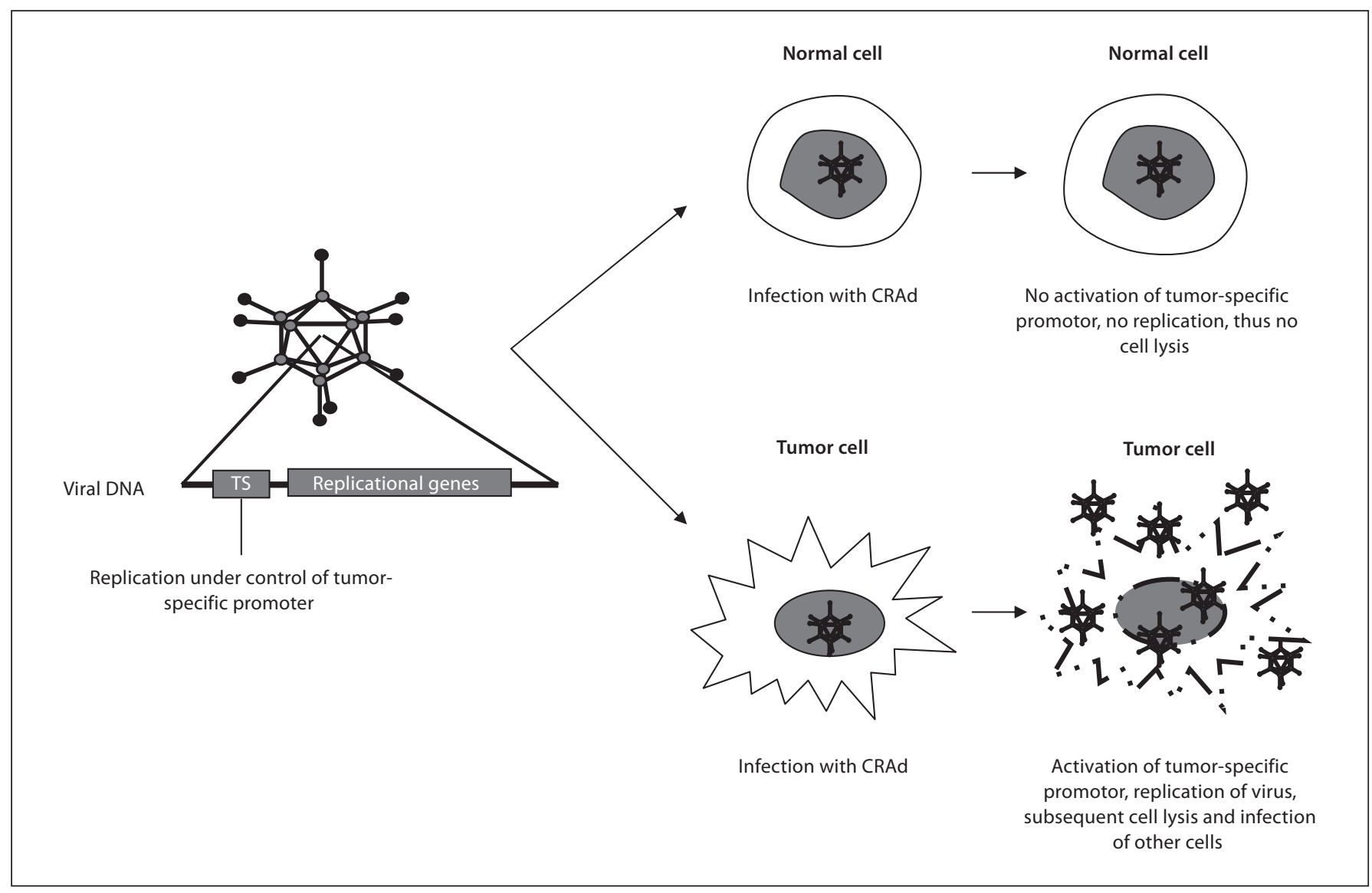

Fig. 3. Conditionally replicating adenovirus.

for this purpose [95]. Midkine (MK), a heparin-binding growth factor and cyclooxygenase-2 (COX-2), a key enzyme in the conversion of arachidonic acid, are both upregulated in pancreatic cancer. Wesseling et al. [96] constructed adenoviral vectors with the luciferase reporter gene under control of $\mathrm{MK}$ and COX-2 and compared it to the cytomegalovirus promoter. Both genes display a socalled 'liver-off, pancreatic cancer-on' expression and did not show significant liver toxicity. Both vectors achieved moderate to high activity upon transduction of primary pancreatic cancer cell lines. Yamamoto et al. [97] constructed a CRAd with a cyclooxygenase (COX-2)-driven E1A gene. Infectivity was enhanced by incorporation of the RGD peptide into the HI loop. The CRAd showed selective cytotoxicity in vitro in COX-2-positive pancreatic cancer cell lines. In a pancreatic cancer xenograft model in mice, intratumoral injection of the retargeted CRAd showed a strong antitumor effect comparable to that of wild-type adenovirus, while the non-targeted CRAd showed limited effect. Other TSPs evaluated for usage in an adenoviral system to treat pancreatic cancer are mucin 1 (MUC1), early growth response gene 1 (Egr-1), and telomerase $[98,99]$. Telomerase is a protein of interest because the vast majority of human tumors have telomerase activity, whereas most benign diseases and normal tissues do not express this enzyme. It is upregulated in approximately $95 \%$ of human pancreatic carcinoma cells, while it is absent in benign pancreatic tissue [100]. It is a ribonucleoprotein enzyme that maintains telomere length through the addition of TTAGGG repeats [101]. Adenoviral vectors with therapeutic or suicide genes driven by the telomerase promoter (mainly hTERT; human telomerase reverse transcriptase) have shown to efficiently kill different cancer cells in vitro and in vivo, in a telomerase-dependent manner [102, 103]. Recently, a hTERT promoter fragment was used to drive the expression of the E1A gene in oncolytic adenoviral vectors, which revealed tumor-selective oncolysis of cancer cells 
in vitro $[104,105]$. Although transductional targeting of Ad proved to be promising, Ad vectors with RGD modification still revealed limited expression in normal tissue. To overcome this obstacle in treatment of melanoma, Okada et al. [106] used an AdRGD-mediated HSV-Tk/ ganciclovir system where the HSV-Tk gene is under the control of the melanoma-specific tyrosinase (Tyr) promotor or tumor-specific telomerase reverse transcriptase (TERT) promotor. Thanks to transcriptional targeting, AdRGD-Tyr/HSV-Tk or AdRGD-TERT/HSV-Tk has the same effect in gene expression compared to the AdRGDCMV/HSV-Tk, but with 10 times less vector dosage of the TSP vectors, indicating that these vectors are effective and safe for melanoma suicide gene therapy.

In the last meeting of the American Society of Gene Therapy in Seattle in May 2007, many interesting abstracts were presented concerning replicative adenoviral vectors. Initial experience in a phase I study with a telomerase-specific CRAd suggests that the virus is safe and well tolerated. Pathological examination showed activity at the tumor site in patients with solid tumors [107]. Terao et al. [108] presented an in vitro study using a MK-promotor based CRAd in a bladder cancer model. A significant antitumor effect was shown in cell lines overexpressing MK mRNA. This is interesting because earlier studies showed overexpression of the MK promoter in pancreatic cancer [96]. Because most animal models do not support replication of human adenovirus, Smith et al. [109] developed a canine adenovirus which was studied in a fully immunocompetent dog model with osteosarcoma. The model showed to be safe. Experiments with models like this are essential for the further application of CRAds in humans.

In conclusion, transcriptional targeting is evolving quickly but essential drawbacks delay the clinical application of the developed viruses. For example, the replicating viruses should first be tested in animal models, but the most commonly used mice model cannot be used because adenoviruses do not replicate in the mice. Questions concerning the activity of TSPs in the targeted tissue should be addressed. Furthermore, the efficacy of replicating adenoviral vectors is questioned in a hypoxic environment. Because hypoxia is a pathophysiological condition in cancer, Shen et al. [110] investigated the lytic potential of the replication-competent adenoviral vector. They demonstrate that hypoxia does not alter receptor-mediated viral uptake, but alters the viral replication and cytolysis in a viral- and cell-specific manner. Studies with replication vectors in a hypoxic environment should further address this problem.
A final problem is the biosafety issue when replicating viruses are brought from bench to bedside. What would be the consequences of a recombination of the engineered virus with a related wild-type virus in the population? Unfortunately, most phase I clinical trials do not address the topic of viral shedding and recombination with wildtype virus. Until these issues are investigated sufficiently, maximum safety precautions should be undertaken [111].

\section{Adenoviral Vectors and Chemoradiation}

Multiple preclinical trials have investigated the effect of combining adenoviral vectors with chemo- or radiotherapy. Gemcitabine has become widely used in the treatment of advanced pancreatic cancer.

Halloran et al. [112] performed combining experiments with adenovirus-mediated delivery of $p 53$ or $p 16$ and 5-fluorouracil (5-FU) or gemcitabine in pancreatic cancer cell lines. They showed that the combination of use of 5-FU or gemcitabine with restoration of p16 expression resulted in a significant increase in apoptotic cells compared with controls. Furthermore, the combination facilitated the use of chemotherapeutic drugs at lower concentrations than would otherwise be effective. Wack et al. [113] investigated whether pancreatic cancer cells could be sensitized to gemcitabine chemotherapy by cotreatment with an adenoviral hTERT-targeted proapoptotic gene expression vector using the proapoptotic genes Bax and TNF-related apoptosis-inducing ligand (TRAIL). In cell lines and an orthotopic tumor model, this combined treatment resulted in a significant tumor regression and prolongation of the experimental animal's life compared to gemcitabine alone. Adenoviral vectors can also enhance the efficacy of radiotherapy. Radiotherapy is hampered by tumor hypoxia. Liu et al. [114] used a bacterial cytosine deaminase (bCD) adenoviral gene therapy system which employed the hypoxia-response element promoter to regulate bCD transcription. They also show significantly improved tumor response in cell lines as well as tumor xenografts. These studies show the importance of adenoviral vectors in the improvement of established treatment strategies.

\section{Clinical Trials}

Although a lot of experimental work has been performed, only few clinical trials utilizing adenoviral gene therapy have been performed in patients with pancreatic cancer today (table 1a, b). Mulvihill et al. [115] performed 
Table 1a. Overview of experimental studies concerning adenoviral gene therapy in pancreatic cancer

\begin{tabular}{|c|c|c|c|c|c|}
\hline Type of Ad vector & Serotype & Type of modification & Gene to be transduced & $\begin{array}{l}\text { In vitro/ } \\
\text { in vivo }\end{array}$ & Ref. \\
\hline \multirow[t]{2}{*}{ Fiber knob modification } & Ad5 & RGD in HI loop & LUC & In vivo & 18 \\
\hline & Ad5 & $\begin{array}{l}\text { TRAIL gene driven by the hTERT } \\
\text { promoter; RGD in HI loop }\end{array}$ & TRAIL gene & $\begin{array}{l}\text { In vivo, } \\
\text { in vitro }\end{array}$ & 25 \\
\hline $\begin{array}{l}\text { Fiber-chimeric } \\
\text { adenoviruses }\end{array}$ & Ad5/16 & Fiber chimera & GFP & In vitro & $\begin{array}{l}\text { Sub- } \\
\text { mitted }\end{array}$ \\
\hline \multirow[t]{2}{*}{ Serotype switch } & $\operatorname{Ad} 35$ & Unmodified & None & In vitro & 51,54 \\
\hline & Ad11 & Unmodified & GFP & In vitro & 53 \\
\hline $\begin{array}{l}\text { Bispecific adaptor } \\
\text { molecules complexed } \\
\text { with Ad5 }\end{array}$ & Ad5 & $\begin{array}{l}\text { Epidermal growth factor receptor targeting using } \\
\text { bispecific antibody recognizing knob of Ad5 and } \\
\text { EGFR receptor }\end{array}$ & LUC & In vitro & 18 \\
\hline \multirow{6}{*}{$\begin{array}{l}\text { Restoration or silencing } \\
\text { of pancreatic cancer- } \\
\text { specific genes }\end{array}$} & Ad5 & $\begin{array}{l}\text { Vector containing antisense human } \\
\text { K-ras RNA }\end{array}$ & Antisense human K-ras RNA & In vivo & 77 \\
\hline & $\overline{\mathrm{Ad} 5}$ & $\begin{array}{l}\text { Vector containing antisense human } \\
\text { K-ras RNA and interferon- } \alpha\end{array}$ & $\begin{array}{l}\text { Antisense human K-ras RNA } \\
\text { and interferon- } \alpha\end{array}$ & In vitro & 78 \\
\hline & $\overline{\mathrm{Ad} 5}$ & $\begin{array}{l}\text { Vector containing antisense RNA to cancer-associated } \\
\text { Sm-like oncogene (CaSm) }\end{array}$ & Antisense RNA to CaSm & $\begin{array}{l}p 53 \text { and } \\
p 16\end{array}$ & 79 \\
\hline & $\overline{\mathrm{Ad} 5}$ & $\begin{array}{l}\text { Vector containing the wild-type } p 53 \\
\text { tumor-suppressor gene }\end{array}$ & Wild-type P53 & In vivo & 80 \\
\hline & $\overline{\mathrm{Ad} 5}$ & $\begin{array}{l}\text { Vector containing the wild-type retinoblastoma } \\
\text { tumor-suppressor gene }\end{array}$ & Wild-type $R b$ & In vivo & 81 \\
\hline & & $\begin{array}{l}\text { Vector containing the wild-type } p 53 \text { and } p 16 \\
\text { tumor-suppressor gene }\end{array}$ & Wild-type $p 53$ and $p 16$ & $\begin{array}{l}p 53 \text { and } \\
p 16\end{array}$ & 82 \\
\hline Transcriptional targeting & Ad5 & $\begin{array}{l}\text { Vector containing tissue inhibitors of } \\
\text { metalloproteinase } 1 \text { and } 2 \text { (TIMP1 and TIMP2) }\end{array}$ & TIMP1; TIMP2 & $\begin{array}{l}\text { In vitro, } \\
\text { in vivo }\end{array}$ & 83 \\
\hline \multirow[t]{2}{*}{$\begin{array}{l}\text { Gene-directed prodrug } \\
\text { activation therapy }\end{array}$} & Ad5 & Vector containing cytosine deaminase (CD) & $\mathrm{CD}$ & $\begin{array}{l}\text { In vitro, } \\
\text { in vivo }\end{array}$ & 84 \\
\hline & Ad5 & Vector containing thymidine kinase (TK) & TK & $\begin{array}{l}\text { In vitro, } \\
\text { in vivo }\end{array}$ & 85 \\
\hline \multirow[t]{3}{*}{$\begin{array}{l}\text { Conditionally replicating } \\
\text { adenoviruses (CRAd) }\end{array}$} & Ad5 & Midkine and COX2 promotor & $\begin{array}{l}\text { Tumor-specific expression of } \\
\text { LUC and thymidine kinase }\end{array}$ & In vitro & 96 \\
\hline & $\overline{\text { Ad5 }}$ & COX-2 promotor CRAd and RGD-COX-2 CRAd & oncolytic: mutant E1B & $\begin{array}{l}\text { In vitro, } \\
\text { in vivo }\end{array}$ & 97 \\
\hline & Ad5 & Mucin promotor & $\begin{array}{l}\text { Tumor-specific expression of } \\
\text { somatostatin }\end{array}$ & In vitro & 99 \\
\hline
\end{tabular}

LUC = Luciferase; GFP = green fluorescent protein.

Table 1b. Overview of clinical studies concerning adenoviral gene therapy in pancreatic cancer

\begin{tabular}{|c|c|c|c|c|c|}
\hline Type of Ad vector & Serotype & Type of modification & Gene to be transduced & Trial phase & Ref. \\
\hline \multirow[t]{2}{*}{$\begin{array}{l}\text { Conditionally replicating } \\
\text { adenoviruses (CRAd) }\end{array}$} & $\operatorname{Ad} 5 / 2$ & ONYX-015 (E1B gene absent) & $\begin{array}{l}\text { Oncolytic: only replicates in p } 53 \\
\text { deficient cells, intratumoral injection }\end{array}$ & $\mathrm{I}$ & 115 \\
\hline & $\overline{\mathrm{Ad} 5 / 2}$ & ONYX-015 (E1B gene absent) & $\begin{array}{l}\text { Oncolytic: only replicates in p53 } \\
\text { deficient cells, intratumoral injection }\end{array}$ & $\mathrm{I} / \mathrm{II}$ & 87 \\
\hline \multirow[t]{2}{*}{$\begin{array}{l}\text { Adenovirus carrying } \\
\text { gene with antitumor } \\
\text { effect }\end{array}$} & Ad5 & $\begin{array}{l}\text { Vector containing human tumor necrosis } \\
\text { factor- } \alpha \text { under control of the } \\
\text { radiation-inducible Egr-1 promoter }\end{array}$ & TNF- $\alpha$; intratumoral injection & I & 117 \\
\hline & $\overline{\mathrm{Ad} 5}$ & $\begin{array}{l}\text { Vector containing interleukin- } \\
12 \text { gene }\end{array}$ & Interleukin-12; intratumoral injection & $\mathrm{I}$ & 116 \\
\hline
\end{tabular}


a phase I study with CT-guided or preoperative intratumoral injection of ONYX-015 in 23 patients, which was published in 2001. They showed that this is a feasible and well-tolerated therapy, although viral replication was not detectable. Hecht et al. [87] performed a phase I/II trial in 2003 of endoscopic intratumoral injection of ONYX015 with intravenous gemcitabine in patients with unresectable pancreatic carcinoma. This study also showed that the treatment strategy was feasible and was generally well tolerated. Again, no replication was detectable. In 2004, Sangro et al. [116] performed a phase I trial to evaluate intratumoral injection of an adenoviral vector carrying the interleukin-12 gene in patients with advanced digestive tumors. Seven of 21 included patients were bearing an advanced pancreatic tumor. This study concluded that the treatment was feasible and well tolerated; however, only mild antitumor effects were observed. TNFerade ${ }^{\mathrm{TM}}$, a replication-deficient adenoviral vector that expresses human tumor necrosis factor- $\alpha$ under control of the radiation-inducible Egr-1 promoter, was tested in a phase I study and was shown to be feasible and well tolerated in patients with different solid tumors including pancreatic cancer [117]. The therapeutic role of this vector is being investigated in patients with pancreatic, esophageal and rectal cancer. No phase III studies for pancreatic cancer are being performed at this moment.

When results of phase III adenoviral gene therapy trials for other malignancies are summarized, conclusions are disappointing. Worldwide, only 9 phase III trials using adenoviral vectors are being performed at this moment, 7 of them for cancer diseases (http://www.wiley. co.uk/genmed/clinical/). Six trials are investigating the therapeutic effect of adenoviral restoration of the mutated P53 tumor-suppressor gene in carcinoma of the head and neck. One study is investigating replication-competent adenovirus-mediated suicide gene therapy in prostate cancer. Up to now, no phase III study has proved to be more effective than existing treatments for tumors.

\section{Perspectives}

In this review, we have focused on the ongoing development of adenoviral vectors for the treatment of pancreatic cancer. We summarized the different strategies that have been explored to improve adenoviral vectors. During the past decade, adenoviral vectors have been modified to target cells of interest, and furthermore they have been modified to restore tumor-suppressor genes or si- lence gene defects or to specifically replicate in a target cell.

Unfortunately, a clear therapeutic effect has not yet been achieved. Several reasons could explain these poor results. The neutralization of the virus by the immune system and binding to blood cells play an important role, particularly after systemic administration. This could be encountered by intratumoral injection, although this will decrease the systemic effect on possible metastatic tissue. Other reasons are the anatomical barriers in a solid tumor. Viral spread inside the tumor could be hampered by the tightness of tumor cells and the surrounding fibrotic tissue.

To achieve a therapeutic effect in the future, the different strategies of adenoviral improvement should be combined. Ideally, a targeted vector containing a modified capsid should be combined with an oncolytic adenoviral vector. This vector should be altered or packaged to bypass innate and acquired immunogenicity and neutralization by blood cells. Furthermore, it should be administered systemically to reach distant metastatic tissue as well micrometastases. Although preclinical trials have highlighted some benefits and limitations of oncolytic adenoviral treatment, clinical trials are needed to understand the optimal way of delivery and antitumor response in humans, because animal models are often not comparable to human physiology.

Although considerable research and studies are still needed to optimize the transduction efficiency and oncolytic effect of targeted adenoviral vectors, steady improvements have been achieved during the last decade. The development of new generations of oncolytic adenoviral vectors, including various ways of targeting pancreatic cancer, will hopefully provide a new anticancer agent for multimodal pancreatic cancer treatment. Most likely, the best optimal effect in these severely ill patients will be achieved when the virus is administered in combination with existing chemotherapy and radiation therapy.
References
Jemal A, Siegel R, Ward E, Hao Y, Xu J, Mur ray T, Thun MJ: Cancer statistics, 2008. CA Cancer J Clin 2008;58:71-96.

2 Kuhlmann KF, De Castro SM, Wesseling JG, ten Kate FJ, Offerhaus GJ, Busch OR, van Gulik TM, Obertop H, Gouma DJ: Surgical treatment of pancreatic adenocarcinoma; actual survival and prognostic factors in 343 patients. Eur J Cancer 2004;40:549-558. 
3 Neoptolemos JP, Stocken DD, Friess H, Bassi C, Dunn JA, Hickey H, Beger H, FernandezCruz L, Dervenis C, Lacaine F, Falconi M, Pederzoli P, Pap A, Spooner D, Kerr DJ, Büchler MW: A randomized trial of chemoradiotherapy and chemotherapy after resection of pancreatic cancer. N Engl J Med 2004; 350:1200-1210.

$\checkmark 4$ Haller DG: Future directions in the treatment of pancreatic cancer. Semin Oncol 2002;29:31-39.

5 Ryan DP, Willett CG: Management of locally advanced adenocarcinoma of the pancreas. Hematol Oncol Clin North Am 2002;16:95103.

6 Kaufman HL, Di VJ Jr, Horig H: Immunotherapy for pancreatic cancer: current concepts. Hematol Oncol Clin North Am 2002; 16:159-97, viii.

7 Sener SF, Fremgen A, Menck HR, Winchester DP: Pancreatic cancer: a report of treatment and survival trends for 100,313 patients diagnosed from 1985-1995, using the National Cancer Database. J Am Coll Surg 1999;189: $1-7$.

8 Shenk T: Adenoviridae; in Knipe DM, Howley PM (eds): Fields Virology. Philadelphia, Lippincott Williams \& Wilkins, 2001, vol 2, pp 2265-2301.

-9 Havenga MJ, Lemckert AA, Ophorst OJ, van Meijer M, Germeraad WT, Grimbergen J, van Den Doel MA, Vogels R, van Deutekom J, Janson AA, de Bruijn JD, Uytdehaag F, Quax PH, Logtenberg T, Mehtali M, Bout A: Exploiting the natural diversity in adenovirus tropism for therapy and prevention of disease. J Virol 2002;76:4612-4620.

-10 Alemany R, Curiel DT: CAR-binding ablation does not change biodistribution and toxicity of adenoviral vectors. Gene Ther 2001;8:1347-1353.

-11 Yun CO, Yoon AR, Yoo JY, Kim H, Kim M, Ha T, Kim GE, Kim H, Kim JH: Coxsackie and adenovirus receptor binding ablation reduces adenovirus liver tropism and toxicity. Hum Gene Ther 2005;16:248-261.

- 12 Lieber A, He CY, Meuse L, Schowalter D, Kirillova I, Winther B, Kay MA: The role of Kupffer cell activation and viral gene expression in early liver toxicity after infusion of recombinant adenovirus vectors. J Virol 1997;71:8798-8807.

-13 Bergelson JM, Cunningham JA, Droguett G, Kurt-Jones EA, Krithivas A, Hong JS, Horwitz MS, Crowell RL, Finberg RW: Isolation of a common receptor for coxsackie B viruses and adenoviruses 2 and 5. Science 1997; 275:1320-1323.

-14 Dmitriev I, Krasnykh V, Miller CR, Wang M, Kashentseva E, Mikheeva G, Belousova N, Curiel DT: An adenovirus vector with genetically modified fibers demonstrates expanded tropism via utilization of a coxsackievirus and adenovirus receptor-independent cell entry mechanism. J Virol 1998;72:97069713.

Adenoviral Gene Therapy for Pancreatic Cancer
15 Dechecchi MC, Melotti P, Bonizzato A, Santacatterina M, Chilosi M, Cabrini G: Heparan sulfate glycosaminoglycans are receptors sufficient to mediate the initial binding of adenovirus types 2 and 5. J Virol 2001; 75:8772-8780.

16 Hong SS, Karayan L, Tournier J, Curiel DT, Boulanger PA: Adenovirus type 5 fiber knob binds to MHC class I $\alpha 2$ domain at the surface of human epithelial and B lymphoblastoid cells. EMBO J 1997;16:2294-2306.

17 Thomas CE, Ehrhardt A, Kay MA: Progress and problems with the use of viral vectors for gene therapy. Nat Rev Genet 2003;4:346358 .

18 Wesseling JG, Bosma PJ, Krasnykh V, Kashentseva EA, Blackwell JL, Reynolds PN, Li H, Parameshwar M, Vickers SM, Jaffee EM, Huibregtse K, Curiel DT, Dmitriev I: Improved gene transfer efficiency to primary and established human pancreatic carcinoma target cells via epidermal growth factor receptor and integrin-targeted adenoviral vectors. Gene Ther 2001;8:969-976.

19 Pearson AS, Koch PE, Atkinson N, Xiong M, Finberg RW, Roth JA, Fang B: Factors limiting adenovirus-mediated gene transfer into human lung and pancreatic cancer cell lines. Clin Cancer Res 1999;5:4208-4213.

20 Kim M, Zinn KR, Barnett BG, Sumerel LA, Krasnykh V, Curiel DT, Douglas JT: The therapeutic efficacy of adenoviral vectors for cancer gene therapy is limited by a low level of primary adenovirus receptors on tumour cells. Eur J Cancer 2002;38:1917-1926.

21 Crystal RG, Harvey BG, Wisnivesky JP, O’Donoghue KA, Chu KW, Maroni J, Muscat JC, Pippo AL, Wright CE, Kaner RJ, Leopold PL, Kessler PD, Rasmussen HS, Rosengart TK, Hollmann C: Analysis of risk factors for local delivery of low- and intermediatedose adenovirus gene transfer vectors to individuals with a spectrum of comorbid conditions. Hum Gene Ther 2002;13:65-100.

22 Krasnykh V, Dmitriev I, Mikheeva G, Miller CR, Belousova N, Curiel DT: Characterization of an adenovirus vector containing a heterologous peptide epitope in the HI loop of the fiber knob. J Virol 1998;72:1844-1852.

23 Krasnykh V, Dmitriev I, Mikheeva G, Miller CR, Belousova N, Curiel DT: Characterization of an adenovirus vector containing a heterologous peptide epitope in the HI loop of the fiber knob. J Virol 1998;72:18441852 .

24 Koizumi N, Mizuguchi H, Utoguchi N, Watanabe Y, Hayakawa T: Generation of fiber-modified adenovirus vectors containing heterologous peptides in both the HI loop and $\mathrm{C}$ terminus of the fiber knob. J Gene Med 2003;5:267-276.

25 Jacob D, Davis JJ, Zhang L, Zhu H, Teraishi F, Fang B: Suppression of pancreatic tumor growth in the liver by systemic administration of the TRAIL gene driven by the hTERT promoter. Cancer Gene Ther 2005;12:109115.
26 Mizuguchi H, Hayakawa T: Enhanced antitumor effect and reduced vector dissemination with fiber-modified adenovirus vectors expressing herpes simplex virus thymidine kinase. Cancer Gene Ther 2002;9:236-242.

27 Nicklin SA, White SJ, Watkins SJ, Hawkins $\mathrm{RE}$, Baker AH: Selective targeting of gene transfer to vascular endothelial cells by use of peptides isolated by phage display. Circulation 2000;102:231-237.

28 Xia H, Anderson B, Mao Q, Davidson BL: Recombinant human adenovirus: targeting to the human transferrin receptor improves gene transfer to brain microcapillary endothelium. J Virol 2000;74:11359-11366.

29 Nicklin SA, Dishart KL, Buening H, Reynolds PN, Hallek M, Nemerow GR, Von Seggern DJ, Baker AH: Transductional and transcriptional targeting of cancer cells using genetically engineered viral vectors. Cancer Lett 2003;201:165-173.

30 Dmitriev IP, Kashentseva EA, Curiel DT: Engineering of adenovirus vectors containing heterologous peptide sequences in the $\mathrm{C}$ terminus of capsid protein IX. J Virol 2002;76: 6893-6899.

31 Meulenbroek RA, Sargent KL, Lunde J, Jasmin BJ, Parks RJ: Use of adenovirus protein IX (pIX) to display large polypeptides on the virion-generation of fluorescent virus through the incorporation of pIX-GFP. Mol Ther 2004;9:617-624.

32 Vellinga J, Rabelink MJ, Cramer SJ, van den Wollenberg DJ, Van der MH, Leppard KN, Fallaux FJ, Hoeben RC: Spacers increase the accessibility of peptide ligands linked to the carboxyl terminus of adenovirus minor capsid protein IX. J Virol 2004;78:3470-3479.

33 Wickham TJ, Carrion ME, Kovesdi I: Targeting of adenovirus penton base to new receptors through replacement of its RGD motif with other receptor-specific peptide motifs. Gene Ther 1995;2:750-756.

34 Vigne E, Mahfouz I, Dedieu JF, Brie A, Perricaudet $M$, Yeh $P$ : RGD inclusion in the hexon monomer provides adenovirus type 5based vectors with a fiber knob-independent pathway for infection. J Virol 1999;73:51565161.

35 Roelvink PW, Lizonova A, Lee JG, Li Y, Bergelson JM, Finberg RW, Brough DE, Kovesdi I, Wickham TJ: The coxsackievirus-adenovirus receptor protein can function as a cellular attachment protein for adenovirus serotypes from subgroups A, C, D, E, and F. J Virol 1998;72:7909-7915.

36 Gall J, Kass-Eisler A, Leinwand L, Falck-Pedersen E: Adenovirus type 5 and 7 capsid chimera: fiber replacement alters receptor tropism without affecting primary immune neutralization epitopes. J Virol 1996;70: 2116-2123.

37 Stevenson SC, Rollence M, Marshall-Neff J, McClelland A: Selective targeting of human cells by a chimeric adenovirus vector containing a modified fiber protein. J Virol 1997;71:4782-4790. 
-38 Mizuguchi H, Hayakawa T: Adenovirus vectors containing chimeric type 5 and type 35 fiber proteins exhibit altered and expanded tropism and increase the size limit of foreign genes. Gene 2002;285:69-77.

-39 Gaggar A, Shayakhmetov DM, Lieber A: CD46 is a cellular receptor for group B adenoviruses. Nat Med 2003;9:1408-1412.

-40 Segerman A, Atkinson JP, Marttila M, Dennerquist V, Wadell G, Arnberg N: Adenovirus type 11 uses CD46 as a cellular receptor. J Virol 2003;77:9183-9191.

-41 Short JJ, Pereboev AV, Kawakami Y, Vasu C, Holterman MJ, Curiel DT: Adenovirus serotype 3 utilizes CD80 (B7.1) and CD86 (B7.2) as cellular attachment receptors. Virology 2004;322:349-359.

-42 Arnberg N, Kidd AH, Edlund K, Olfat F, Wadell G: Initial interactions of subgenus D adenoviruses with A549 cellular receptors: sialic acid versus $\alpha(v)$ integrins. J Virol 2000; 74:7691-7693.

-43 Burmeister WP, Guilligay D, Cusack S, Wadell G, Arnberg N: Crystal structure of species $\mathrm{D}$ adenovirus fiber knobs and their sialic acid binding sites. J Virol 2004;78: 7727-7736.

44 Goossens PH, Havenga MJ, Pieterman E, Lemckert AA, Breedveld FC, Bout A, Huizinga TW: Infection efficiency of type 5 adenoviral vectors in synovial tissue can be enhanced with a type 16 fiber. Arthritis Rheum 2001;44:570-577.

45 Havenga MJ, Lemckert AA, Grimbergen JM, Vogels R, Huisman LG, Valerio D, Bout A, Quax PH: Improved adenovirus vectors for infection of cardiovascular tissues. J Virol 2001;75:3335-3342.

46 Shayakhmetov DM, Papayannopoulou T, Stamatoyannopoulos G, Lieber A: Efficient gene transfer into human CD34+ cells by a retargeted adenovirus vector. J Virol 2000; 74:2567-2583.

47 Lecollinet S, Gavard F, Havenga MJ, Spiller OB, Lemckert A, Goudsmit J, Eloit M, Richardson J: Improved gene delivery to intestinal mucosa by adenoviral vectors bearing subgroup B and d fibers. J Virol 2006;80: 2747-2759.

-48 Borovjagin AV, Krendelchtchikov A, Ramesh N, Yu DC, Douglas JT, Curiel DT: Complex mosaicism is a novel approach to infectivity enhancement of adenovirus type 5-based vectors. Cancer Gene Ther 2005;12: 475-486.

49 Sumida SM, Truitt DM, Lemckert AA, Vogels R, Custers JH, Addo MM, Lockman S, Peter T, Peyerl FW, Kishko MG, Jackson SS, Gorgone DA, Lifton MA, Essex M, Walker BD, Goudsmit J, Havenga MJ, Barouch DH: Neutralizing antibodies to adenovirus serotype 5 vaccine vectors are directed primarily against the adenovirus hexon protein. J Immunol 2005; 174:7179-7185.
50 Roy S, Shirley PS, McClelland A, Kaleko M: Circumvention of immunity to the adenovirus major coat protein hexon. J Virol 1998; 72:6875-6879.

-51 Vogels R, Zuijdgeest D, van Rijnsoever R, Hartkoorn E, Damen I, de Bethune MP, Kostense S, Penders G, Helmus N, Koudstaal W, Cecchini M, Wetterwald A, Sprangers M, Lemckert A, Ophorst O, Koel B, van Meerendonk M, Quax P, Panitti L, Grimbergen J, Bout A, Goudsmit J, Havenga M: Replication-deficient human adenovirus type 35 vectors for gene transfer and vaccination: efficient human cell infection and bypass of preexisting adenovirus immunity. J Virol 2003;77:8263-8271.

52 Nwanegbo E, Vardas E, Gao W, Whittle H, Sun H, Rowe D, Robbins PD, Gambotto A: Prevalence of neutralizing antibodies to adenoviral serotypes 5 and 35 in the adult populations of The Gambia, South Africa, and the United States. Clin Diagn Lab Immunol 2004;11:351-357.

53 Holterman L, Vogels R, van den Vlugt, Sieuwerts M, Grimbergen J, Kaspers J, Geelen E, van der Helm E, Lemckert A, Gillissen G, Verhaagh S, Custers J, Zuijdgeest D, Berkhout B, Bakker M, Quax P, Goudsmit J, Havenga $M$ : Novel replication-incompetent vector derived from adenovirus type 11 (Ad11) for vaccination and gene therapy: low seroprevalence and non-cross-reactivity with Ad5. J Virol 2004;78:13207-13215.

54 Gao W, Robbins PD, Gambotto A: Human adenovirus type 35: nucleotide sequence and vector development. Gene Ther 2003;10: 1941-1949.

55 Krasnykh V, Belousova N, Korokhov N, Mikheeva G, Curiel DT: Genetic targeting of an adenovirus vector via replacement of the fiber protein with the phage T4 fibritin. J Virol 2001;75:4176-4183.

56 Van Beusechem VW, van Rijswijk AL, van Es $\mathrm{HH}$, Haisma HJ, Pinedo HM, Gerritsen WR: Recombinant adenovirus vectors with knobless fibers for targeted gene transfer. Gene Ther 2000; 7:1940-1946.

57 Belousova N, Korokhov N, Krendelshchikova V, Simonenko V, Mikheeva G, Triozzi PL, Aldrich WA, Banerjee PT, Gillies SD, Curiel DT, Krasnykh V: Genetically targeted adenovirus vector directed to CD40-expressing cells. J Virol 2003;77:11367-11377.

58 Bewley MC, Springer K, Zhang YB, Freimuth P, Flanagan JM: Structural analysis of the mechanism of adenovirus binding to its human cellular receptor, CAR. Science 1999; 286:1579-1583.

59 Roelvink PW, Mi LG, Einfeld DA, Kovesdi I, Wickham TJ: Identification of a conserved receptor-binding site on the fiber proteins of CAR-recognizing adenoviridae. Science 1999;286:1568-1571.
60 Mizuguchi H, Koizumi N, Hosono T, IshiiWatabe A, Uchida E, Utoguchi N, Watanabe Y, Hayakawa T: CAR- or $\alpha \mathrm{V}$ integrin-binding ablated adenovirus vectors, but not fibermodified vectors containing RGD peptide, do not change the systemic gene transfer properties in mice. Gene Ther 2002;9:769776.

61 Leissner P, Legrand V, Schlesinger Y, Hadji DA, van Raaij M, Cusack S, Pavirani A, Mehtali M: Influence of adenoviral fiber mutations on viral encapsidation, infectivity and in vivo tropism. Gene Ther 2001;8:4957.

62 Einfeld DA, Schroeder R, Roelvink PW, Lizonova A, King CR, Kovesdi I, Wickham TJ: Reducing the native tropism of adenovirus vectors requires removal of both CAR and integrin interactions. J Virol 2001;75:1128411291.

63 Koizumi N, Mizuguchi H, Sakurai F, Yamaguchi T, Watanabe Y, Hayakawa T: Reduction of natural adenovirus tropism to mouse liver by fiber-shaft exchange in combination with both CAR- and $\alpha \mathrm{V}$ integrin-binding ablation. J Virol 2003;77:13062-13072.

64 Martin K, Brie A, Saulnier P, Perricaudet M, Yeh P, Vigne E: Simultaneous CAR- and $\alpha \mathrm{V}$ integrin-binding ablation fails to reduce Ad5 liver tropism. Mol Ther 2003;8:485-494.

65 Shayakhmetov DM, Lieber A: Dependence of adenovirus infectivity on length of the fiber shaft domain. J Virol 2000;74:1027410286.

66 Nakamura T, Sato K, Hamada H: Reduction of natural adenovirus tropism to the liver by both ablation of fiber-coxsackievirus and adenovirus receptor interaction and use of replaceable short fiber. J Virol 2003;77:25122521.

67 Smith TA, Idamakanti N, Rollence ML, Marshall-Neff J, Kim J, Mulgrew K, Nemerow GR, Kaleko M, Stevenson SC: Adenovirus serotype 5 fiber shaft influences in vivo gene transfer in mice. Hum Gene Ther 2003;14: 777-787.

68 Goldman CK, Rogers BE, Douglas JT, Sosnowski BA, Ying W, Siegal GP, Baird A, Campain JA, Curiel DT: Targeted gene delivery to Kaposi's sarcoma cells via the fibroblast growth factor receptor. Cancer Res 1997;57:1447-1451.

69 Blackwell JL, Miller CR, Douglas JT, Li H, Reynolds PN, Carroll WR, Peters GE, Strong TV, Curiel DT: Retargeting to EGFR enhances adenovirus infection efficiency of squamous cell carcinoma. Arch Otolaryngol Head Neck Surg 1999;125:856-863.

70 Wickham TJ, Segal DM, Roelvink PW, Carrion ME, Lizonova A, Lee GM, Kovesdi I: Targeted adenovirus gene transfer to endothelial and smooth muscle cells by using bispecific antibodies. J Virol 1996;70:68316838. 
-71 Watkins SJ, Mesyanzhinov VV, Kurochkina LP, Hawkins RE: The 'adenobody' approach to viral targeting: specific and enhanced adenoviral gene delivery. Gene Ther 1997;4: 1004-1012.

-72 Lyons M, Onion D, Green NK, Aslan K, Rajaratnam R, Bazan-Peregrino $M$, Phipps $S$, Hale S, Mautner V, Seymour LW, Fisher KD: Adenovirus type 5 interactions with human blood cells may compromise systemic delivery. Mol Ther 2006;14:118-128.

-73 O'Riordan CR, Lachapelle A, Delgado C, Parkes V, Wadsworth SC, Smith AE, Francis GE: PEGylation of adenovirus with retention of infectivity and protection from neutralizing antibody in vitro and in vivo. Hum Gene Ther 1999;10:1349-1358.

-74 Eto Y, Gao JQ, Sekiguchi F, Kurachi S, Katayama K, Maeda M, Kawasaki K, Mizuguchi H, Hayakawa T, Tsutsumi Y, Mayumi T, Nakagawa S: PEGylated adenovirus vectors containing RGD peptides on the tip of PEG show high transduction efficiency and antibody evasion ability. J Gene Med 2005;7: 604-612.

75 Lanciotti J, Song A, Doukas J, Sosnowski B, Pierce G, Gregory R, Wadsworth S, O'Riordan C: Targeting adenoviral vectors using heterofunctional polyethylene glycol FGF2 conjugates. Mol Ther 2003;8:99-107.

76 Sohn TA, Yeo CJ: The molecular genetics of pancreatic ductal carcinoma: a review. Surg Oncol 2000;9:95-101.

-77 Miura Y, Ohnami S, Yoshida K, Ohashi M, Nakano M, Ohnami S, Fukuhara M, Yanagi K, Matsushita A, Uchida E, Asaka M, Yoshida T, Aoki K: Intraperitoneal injection of adenovirus expressing antisense K-ras RNA suppresses peritoneal dissemination of hamster syngeneic pancreatic cancer without systemic toxicity. Cancer Lett 2005;218:5362.

78 Hatanaka K, Suzuki K, Miura Y, Yoshida K, Ohnami S, Kitade Y, Yoshida T, Aoki K: Interferon- $\alpha$ and antisense K-ras RNA combination gene therapy against pancreatic cancer. J Gene Med 2004;6:1139-1148

-79 Kelley JR, Brown JM, Frasier MM, Baron PL, Schweinfest CW, Vournakis JN, Watson DK, Cole DJ: The cancer-associated Sm-like oncogene: a novel target for the gene therapy of pancreatic cancer. Surgery 2000;128:353360 .

-80 Bouvet M, Bold RJ, Lee J, Evans DB, Abbruzzese JL, Chiao PJ, McConkey DJ, Chandra J, Chada S, Fang B, Roth JA: Adenovirus-mediated wild-type p53 tumor suppressor gene therapy induces apoptosis and suppresses growth of human pancreatic cancer. Ann Surg Oncol 1998;5:681-688.

-81 Simeone DM, Cascarelli A, Logsdon CD: Adenoviral-mediated gene transfer of a constitutively active retinoblastoma gene inhibits human pancreatic tumor cell proliferation. Surgery 1997;122:428-433.
82 Ghaneh P, Greenhalf W, Humphreys M, Wilson D, Zumstein L, Lemoine NR, Neoptolemos JP: Adenovirus-mediated transfer of p53 and p16(INK4a) results in pancreatic cancer regression in vitro and in vivo. Gene Ther 2001;8:199-208.

83 Rigg AS, Lemoine NR: Adenoviral delivery of TIMP1 or TIMP2 can modify the invasive behavior of pancreatic cancer and can have a significant antitumor effect in vivo. Cancer Gene Ther 2001;8:869-878.

84 Evoy D, Hirschowitz EA, Naama HA, Li XK, Crystal RG, Daly JM, Lieberman MD: In vivo adenoviral-mediated gene transfer in the treatment of pancreatic cancer. J Surg Res 1997;69:226-231.

85 Block A, Chen SH, Kosai K, Finegold M, Woo SL: Adenoviral-mediated herpes simplex virus thymidine kinase gene transfer: regression of hepatic metastasis of pancreatic tumors. Pancreas 1997; 15:25-34.

86 Bischoff JR, Kirn DH, Williams A, Heise C, Horn S, Muna M, Ng L, Nye JA, SampsonJohannes A, Fattaey A, McCormick F: An adenovirus mutant that replicates selectively in p53-deficient human tumor cells. Science 1996;274:373-376.

87 Hecht JR, Bedford R, Abbruzzese JL, Lahoti S, Reid TR, Soetikno RM, Kirn DH, Freeman SM: A phase I/II trial of intratumoral endoscopic ultrasound injection of ONYX-015 with intravenous gemcitabine in unresectable pancreatic carcinoma. Clin Cancer Res 2003;9:555-561.

88 Rogulski KR, Freytag SO, Zhang K, Gilbert JD, Paielli DL, Kim JH, Heise CC, Kirn DH: In vivo antitumor activity of ONYX-015 is influenced by 53 status and is augmented by radiotherapy. Cancer Res 2000;60:11931196.

89 O'Shea CC, Johnson L, Bagus B, Choi S, Nicholas C, Shen A, Boyle L, Pandey K, Soria C, Kunich J, Shen Y, Habets G, Ginzinger D, McCormick F: Late viral RNA export, rather than p53 inactivation, determines ONYX015 tumor selectivity. Cancer Cell 2004;6: 611-623.

90 Li G, Sham J, Yang J, Su C, Xue H, Chua D, Sun L, Zhang Q, Cui Z, Wu M, Qian Q: Potent antitumor efficacy of an E1B $55-\mathrm{kDa}$ deficient adenovirus carrying murine endostatin in hepatocellular carcinoma. Int J Cancer 2005;113:640-648.

91 Fueyo J, Gomez-Manzano C, Alemany R, Lee PS, McDonnell TJ, Mitlianga P, Shi YX, Levin VA, Yung WK, Kyritsis AP: A mutant oncolytic adenovirus targeting the Rb pathway produces anti-glioma effect in vivo. Oncogene 2000;19:2-12.

-92 Caldas C, Hahn SA, da Costa LT, Redston MS, Schutte M, Seymour AB, Weinstein CL, Hruban RH, Yeo CJ, Kern SE: Frequent somatic mutations and homozygous deletions of the p16 (MTS1) gene in pancreatic adenocarcinoma. Nat Genet 1994;8:27-32.
93 Heise C, Hermiston T, Johnson L, Brooks G, Sampson-Johannes A, Williams A, Hawkins L, Kirn D: An adenovirus E1A mutant that demonstrates potent and selective systemic anti-tumoral efficacy. Nat Med 2000;6:1134-1139.

94 Fukuda K, Abei M, Ugai H, Seo E, Wakayama M, Murata T, Todoroki T, Tanaka N, Hamada H, Yokoyama KK: E1A, E1B double-restricted adenovirus for oncolytic gene therapy of gallbladder cancer. Cancer Res 2003;63:4434-4440.

95 Iacobuzio-Donahue CA, Maitra A, Olsen M, Lowe AW, van Heek NT, Rosty C, Walter K, Sato N, Parker A, Ashfaq R, Jaffee E, Ryu B, Jones J, Eshleman JR, Yeo CJ, Cameron JL, Kern SE, Hruban RH, Brown PO, Goggins M: Exploration of global gene expression patterns in pancreatic adenocarcinoma using cDNA microarrays. Am J Pathol 2003;162:1151-1162.

96 Wesseling JG, Yamamoto M, Adachi Y, Bosma PJ, van Wijland M, Blackwell JL, Li H, Reynolds PN, Dmitriev I, Vickers SM, Huibregtse K, Curiel DT: Midkine and cyclooxygenase-2 promoters are promising for adenoviral vector gene delivery of pancreatic carcinoma. Cancer Gene Ther 2001; 8:990-996

-97 Yamamoto M, Davydova J, Wang M, Siegal GP, Krasnykh V, Vickers SM, Curiel DT: Infectivity enhanced, cyclooxygenase-2 promoter-based conditionally replicative adenovirus for pancreatic cancer. Gastroenterology 2003;125:1203-1218.

$\checkmark 98$ Takahashi T, Namiki Y, Ohno T: Induction of the suicide HSV-Tk gene by activation of the Egr-1 promoter with radioisotopes. Hum Gene Ther 1997;8:827-833.

99 Chen L, Liu Q, Qin R, Le H, Xia R, Li W, Kumar M: Amplification and functional characterization of MUC1 promoter and gene virotherapy via a targeting adenoviral vector expressing hSSTR2 gene in MUC1positive Panc-1 pancreatic cancer cells in vitro. Int J Mol Med 2005;15:617-626.

100 Hiyama E, Kodama T, Shinbara K, Iwao T, Itoh M, Hiyama K, Shay JW, Matsuura Y, Yokoyama T: Telomerase activity is detected in pancreatic cancer but not in benign tumors. Cancer Res 1997;57:326-331.

101 Morin GB: The human telomere terminal transferase enzyme is a ribonucleoprotein that synthesizes TTAGGG repeats. Cell 1989;59:521-529.

102 Majumdar AS, Hughes DE, Lichtsteiner SP, Wang Z, Lebkowski JS, Vasserot AP: The telomerase reverse transcriptase promoter drives efficacious tumor suicide gene therapy while preventing hepatotoxicity encountered with constitutive promoters. Gene Ther 2001;8:568-578. 
103 Bilsland AE, Anderson CJ, FletcherMonaghan AJ, McGregor F, Evans TR, Ganly I, Knox RJ, Plumb JA, Keith WN: Selective ablation of human cancer cells by telomerase-specific adenoviral suicide gene therapy vectors expressing bacterial nitroreductase. Oncogene 2003;22:370-380.

104 Irving J, Wang Z, Powell S, O’Sullivan C, Mok M, Murphy B, Cardoza L, Lebkowski JS, Majumdar AS: Conditionally replicative adenovirus driven by the human telomerase promoter provides broad-spectrum antitumor activity without liver toxicity. Cancer Gene Ther 2004;11:174-185.

105 Huang Q, Zhang X, Wang H, Yan B, Kirkpatrick J, Dewhrist MW, Li CY: A novel conditionally replicative adenovirus vector targeting telomerase-positive tumor cells. Clin Cancer Res 2004;10:1439-1445.

106 Okada Y, Okada N, Mizuguchi H, Hayakawa T, Nakagawa S, Mayumi T: Transcriptional targeting of RGD fiber-mutant adenovirus vectors can improve the safety of suicide gene therapy for murine melanoma. Cancer Gene Ther 2005;12:608-616.

107 Nemunaitis M, Senzer N, Zhang YA, Tong AW, Lamont J, Barve M, Kawamura H, Nemunaitis J: Phase I study of intratumoral (IT) injection of a telomerase specific conditionally replicative adenovirus (CRAd), telomelysin (OBP-301), in patients with advanced solid tumor. Mol Ther 2007, p S279, abstract 728 .
108 Terao S, Shirakawa T, Kubo S, Hamada K, Tagawa M, Takenaka A, Fujisawa M, Gotoh A: Therapeutic efficacy of midkine promotor-based conditionally replicative adenovirus vector for targeting the midkine-expressing human bladder cancer model. Mol Ther 2007, p S242, abstract 631.

109 Smith BF, Curiel DT, Ternovoi VV, Borovjagin AV, Baker HJ, Cox NR, Smith AN, Higginbotham ML, Siegal GP: Administration of an osteosarcoma-targeted canine oncolytic adenovirus in normal and tumoraffected dogs. Mol Ther 2007, p S278, abstract 727.

110 Shen BH, Bauzon M, Hermiston TW: The effect of hypoxia on the uptake, replication and lytic potential of group $B$ adenovirus type 3 (Ad3) and type 11p (Ad11p). Gene Ther 2006;13:986-990.

111 Vile R, Ando D, Kirn D: The oncolytic virotherapy treatment platform for cancer: unique biological and biosafety points to consider. Cancer Gene Ther 2002;9:10621067.

112 Halloran CM, Ghaneh P, Shore S, Greenhalf W, Zumstein L, Wilson D, Neoptolemos JP, Costello E: 5-Fluorouracil or gemcitabine combined with adenoviralmediated reintroduction of p16INK4A greatly enhanced cytotoxicity in Panc-1 pancreatic adenocarcinoma cells. J Gene Med 2004;6:514-525.

113 Wack S, Rejiba S, Parmentier C, Aprahamian M, Hajri A: Telomerase transcriptional targenting of inducible Bax/TRAIL gene therapy improves gemcitabine treatment of pancreatic cancer. Mol Ther 2008;16:252260.
114 Liu J, Harada H, Ogura M, Shibata T, Hiraoka M: Adenovirus-mediated hypoxiatargeting cytosine deaminase gene therapy enhances radiotherapy in tumor xenografts. Br J Cancer 2007;96:1871-1878.

115 Mulvihill S, Warren R, Venook A, Adler A, Randlev B, Heise C, Kirn D: Safety and feasibility of injection with an E1B-55 kDa gene-deleted, replication-selective adenovirus (ONYX-015) into primary carcinomas of the pancreas: a phase I trial. Gene Ther 2001;8:308-315.

116 Sangro B, Mazzolini G, Ruiz J, Herraiz M, Quiroga J, Herrero I, Benito A, Larrache J, Pueyo J, Subtil JC, Olague C, Sola J, Sadaba B, Lacasa C, Melero I, Qian C, Prieto J: Phase I trial of intratumoral injection of an adenovirus encoding interleukin-12 for advanced digestive tumors. J Clin Oncol 2004; 22:1389-1397.

117 Senzer N, Mani S, Rosemurgy A, Nemunaitis J, Cunningham C, Guha C, Bayol N, Gillen M, Chu K, Rasmussen C, Rasmussen H, Kufe D, Weichselbaum R, Hanna N: TNFerade biologic, an adenovector with a radiation-inducible promoter, carrying the human tumor necrosis factor $\alpha$ gene: a phase I study in patients with solid tumors. J Clin Oncol 2004;22:592-601. 